\title{
Fournier's Gangrene
}

\section{Fournier Gangreni}

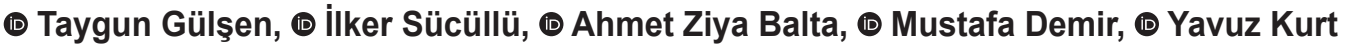 \\ University of Health Sciences, Sultan Abdülhamid Han Training and Research Hospital, Clinic of General Surgery, İstanbul, Turkey
}

\section{HIIIIII|| ABSTRACT}

Fournier's gangrene is a disease of the perineal, genital or perianal regions characterized by necrositic fasciitis due to synergistic polymicrobial infection. Fourteen patients diagnosed with Fournier's gangrene between 2009-2018 in our clinic were evaluated retrospectively. All patients were admitted to the emergency department or outpatient clinic of our hospital. The mean age of the patients was 58.6 (37-81) years. Diabetes mellitus (42\%) and hypertension (42\%) were the most common comorbidities in our patients with Fournier's gangrene. Surgical debridement of necrotic tissues, broad-spectrum antibiotic therapy and nutritional support were applied to all patients. In the second session, reconstructive surgery was performed to repair the wound defect in 3 patients, hyperbaric oxygen therapy in 8 patients, negative pressure dressing in 5 patients, diversion colostomy in 3 patients. Mortality rate was $7 \%$ ( 1 patient). In conclusion, Fournier's gangrene is a serious disease which is seen rarely in the emergencies of general surgery and urology clinics but has high mortality due to its insidious clinic.

Keywords: Debridement, Fournier's gangrene, necrositic fasciitis

\section{||I|||||||| ÖZ}

Fournier gangreni perineal, genital veya perianal bölgelerin, sinerjistik polimikrobiyal enfeksiyonuna bağl gelişen nekrozitan fasitisi ile karakterize bir hastalı̆̆ıdır. Kliniğimizde 2009-2018 tarihleri arasında, Fournier gangreni tanısı konulan 14 hasta retrospektif olarak değerlendirildi. Hastaların tamamı ilk başvuruda hastanemiz acil servisine ya da polikliniğe başvuran hastalardı. Ortalama yaşı 58,6 (37-81) yıl olan olgularımızın ikisi kadın, diğerleri erkekti. Fournier gangreni olgularımızda en sık yandaş hastalıklar diabetes melitus (6 hasta \%42) ve hipertansiyon (6 hasta \%42) idi. Nekrotik dokuların cerrahi debridmanı, geniş spektrumlu antibiyotik tedavisi ve nütrisyonel destek bütün hastalara uygulanırken; yara defektini onarmak için ikinci seansta rekonstrüktif cerrahi girişim 3 hastaya, hiperbarik oksijen tedavisi 8 hastaya, negatif basınçlı pansuman 5 hastaya, diversiyon kolostomisi 3 hastaya uygulandı. Mortalite oranı \%7 (1 hasta) olarak bulundu. Sonuç olarak Fournier gangreni, genel cerrahi ve üroloji kliniklerinin acillerinde nadir görülen, ancak sinsi kliniği nedeniyle yüksek mortaliteye sahip, acil cerrahi girişim gerektiren ciddi bir hastalıktır.

Anahtar Kelimeler: Debridman, Fournier gangreni, nekrotizan fasiit

\section{Introduction}

Fournier's gangrene, first described in 1883 by Jean Alfred Fournier, is an acute and potentially lethal necrotizing fasciitis involving the skin and soft tissues of the scrotum, perineum and even the abdominal wall. ${ }^{1}$ Risk factors for this disease include senility, diabetes, alcoholism, malignancy and immune system suppression. ${ }^{2}$ The most common causes of the disease are anorectal infections, genitourinary infections or local injuries to the perineal and genital skin. ${ }^{3}$ The pathology of Fournier's gangrene can be briefly summarized as synergistic necrotizing fasciitis resulting in the thrombosis of small subcutaneous vessels of suppurative bacterial infection of the anorectal, perineal, or genitourinary regions, leading to the development of gangrene in the skin., ${ }^{1,4}$ With the developing inflammatory reaction, local infection is rapidly spreading to deep fascial layers. This rapidly spreading infection characteristically causes obliterative endarteritis, leading to cutaneous and subcutaneous vascular thrombosis and tissue necrosis. ${ }^{4}$ Because facial necrosis can progress $2-3 \mathrm{~cm}$ per hour, it is very important to make the

Address for Correspondence/Yazışma Adresi: Taygun Gülşen MD,

University of Health Sciences, Sultan Abdülhamid Han Training and Research Hospital, Clinic of General Surgery, İstanbul, Turkey

Phone: +90 5315840059 E-mail: taygun1538@hotmail.com ORCID ID: orcid.org/0000-0002-4536-7776

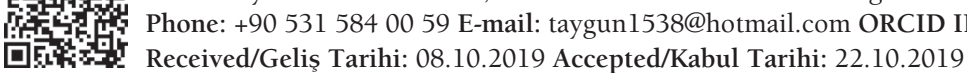

${ }^{\oplus}$ Copyright 2019 by Turkish Society of Colon and Rectal Surgery

Turkish Journal of Colorectal Disease published by Galenos Publishing House. 
diagnosis early. ${ }^{5}$ In this study, we evaluated 14 patients with Fournier's gangrene in terms of etiology, treatment efficacy, morbidity and mortality factors by considering the literature data.

\section{Case Report}

The records of 14 patients who underwent emergency surgical debridement and broad-spectrum combined antibiotic treatment for Fournier's gangrene in our clinic between 2009 and 2018 were retrospectively reviewed. The duration of the disease until the admission, anamnesis and physical examination findings, routine laboratory tests, surgical debridement technique, antibiotic treatment, comorbid diseases, microorganisms growing in infection site swabs, length of hospitalization and location of the lesion were evaluated. Patients undergoing hyperbaric oxygen therapy $(\mathrm{HBO})$ and negative pressure dressing were noted. Fournier Gangrene Severity Index (FSGI), laboratory risk indicator (LRINC) for necrotizing fasciitis and Uludağ FSGI (UFSGI) scores were also calculated. Surgical debridement was applied to all patients under operating room conditions. Surgical debridement was performed by including some intact tissue in the demarcation line detected by inspection and palpation between erythematous-edematous or necrotic tissue and intact tissue.

The mean age of the patients was 58.6 (37-81) years. There were two women and the remaining patients were men. The co-morbidities were diabetes mellitus in six patients, hypertension in six patients, chronic renal failure in one patient, schizophrenia in one patient, Chronic Obstructive Pulmonary disease in one patient and gout in one patient (Table 1). Seven patients were smoking and two patients were drinking alcohol. Redness, swelling and pain were common complaints in the lesion area (Figure 1). The mean duration between the onset of complaints and admission was 4.4 days (range $=2-15$ days). Physical examination revealed necrosis in perianal region in nine patients, in right inguinal region in one patient, in right gluteal region in

Table 1. Co-morbid diseases

\begin{tabular}{ll} 
Comorbidities & $\begin{array}{l}\text { Number of patients } \\
\text { with comorbidities }\end{array}$ \\
\hline Diabetes mellitus & 6 \\
Hypertension & 6 \\
Chronic renal failure & 1 \\
Chronic obstructive pulmonary disease & 1 \\
Gout & 1 \\
Schizophrenia & 1
\end{tabular}

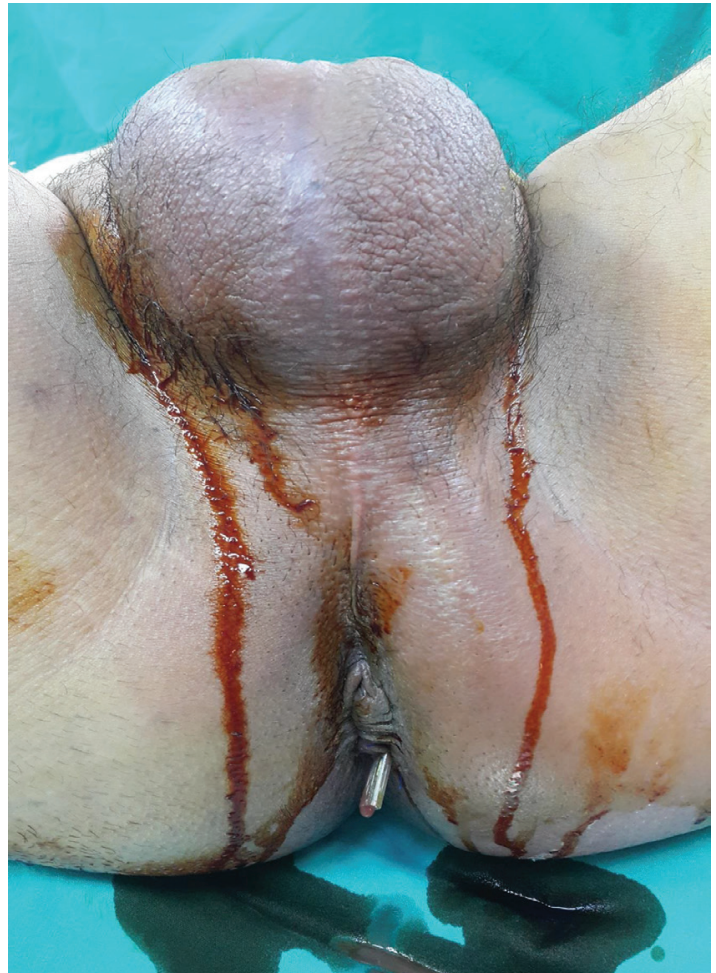

Figure 1. Fournier's gangrene due to swelling and redness after perianal abscess drainage

one patient, extending from perianal region to scrotum in one patient, extending from perianal region to right gluteal region in one patient and extending from perianal region to right gluteal region and right medial thigh in one patient. Laboratory findings revealed a leukocyte number of 36880 in one patient, 28000 in one patient, 22000 in one patient and 20150 in one patient, while leukocyte count was below 15000 in other patients. Alanine aminotransferase level was eight times higher than normal, aspartate aminotransferase level was three times higher than normal and bilirubin level was two times higher than normal in the patient with 28000 leukocytosis. Fasting blood glucose level was $558 \mathrm{mg} / \mathrm{dL}$ in one of the two patients with diabetes mellitus and $427 \mathrm{mg} /$ $\mathrm{dL}$ in the other. The patient who had fasting blood glucose of $181 \mathrm{mg} / \mathrm{dL}$ and did not know that he/she had diabetes mellitus was diagnosed during the diagnosis of Fournier's gangrene. Microbiological examination of tissue swab samples obtained during surgical debridement revealed Escherichia coli in two patients, Proteus mirabilis in one patient and Morganella morgagnii in one patient. There was no growth in the cultures taken from five patients and no culture was obtained from the remaining five patients. After emergency large surgical debridement (Figure 2), the vital functions of the patients returned to normal with the use of broad-spectrum antibiotics; however, one patient died due to sepsis and our mortality rate was $7 \%$. An 81 -year-old 
female patient with mortality was admitted to our clinic 3 days after the onset of her complaints. She had comorbidities such as diabetes mellitus, hypertension and chronic renal failure. The patient underwent debridement and sigmoid loop colostomy. Despite broad-spectrum antibiotherapy and intensive care follow-up, sepsis-related mortality was observed on postoperative seventh day. At the time of admission, the patient's FSGI score was 14, the UFSGI score was 16, and the LRINC score for necrotizing fasciitis was 9. In the second session, reconstructive surgery was performed to repair the wound defect in three patients. HBO was added to eight patients, negative pressure dressing to five patients, and diversion colostomy to three patients. Transverse loop colostomy was performed in one patient and sigmoid loop colostomy was performed in two patients with diversion colostomy. The mean duration of negative pressure dressing was 18 days (range $=9-26$ ). Treatments and blood glucose regulation of diabetic patients were provided by endocrine clinic. FSGI, LRINC and UFSGI scoring systems that evaluate mortality in patients with Fournier's gangrene were calculated individually for our patients. The mean FSGI score was 5.2 (range=1-14), the LRINC score was 5.3 (range=2-9), and the UFSGI score was 7.8 (range=1-16). The mean hospitalization was 17 (range=3-37) days.

\section{Discussion}

Despite the development of various treatment modalities, antibiotic therapy and intensive care follow-up, Fournier's

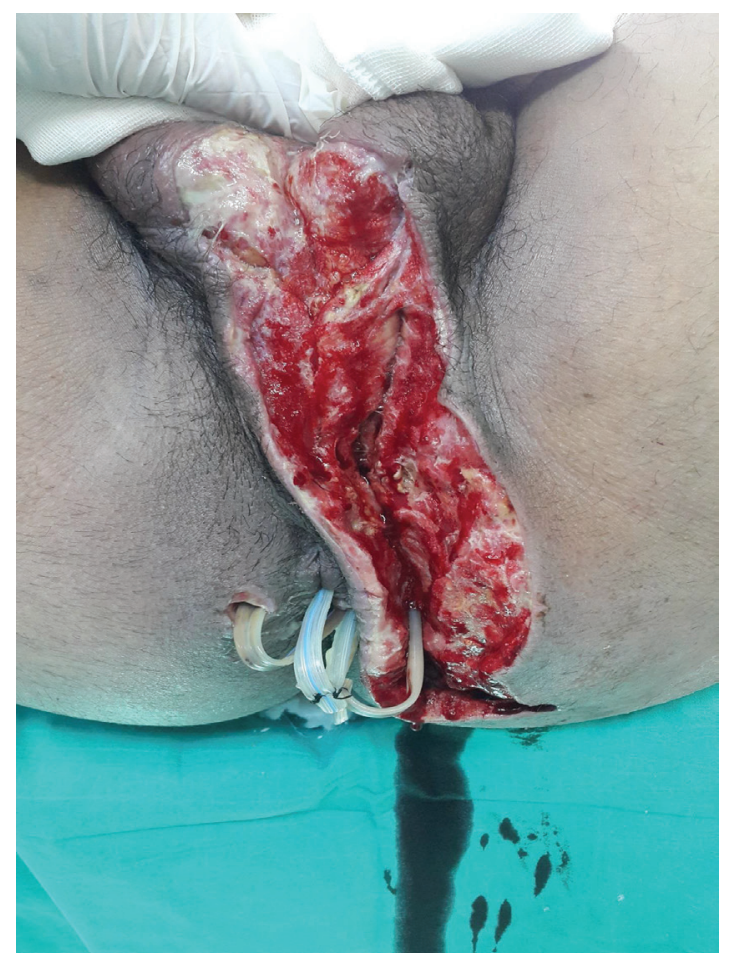

Figure 2. The patient who underwent debridement for Fournier's gangrene gangrene is still a fatal disease with a mortality rate of $20-50 \% .{ }^{6,7}$ In our case series, the mortality rate was $7 \%$. Compared to a recent review of 51.8 years (range $=47-63$ ), our patients were quite old with a mean age of 58.6 years (range $=37-81$ ). ${ }^{8}$ Diabetes mellitus is the most commonly reported comorbidity associated with this disease. ${ }^{9}$ In our case series, six (42\%) of 14 patients had diabetes mellitus. The prevalence of diabetes mellitus in patients with Fournier's gangrene varies between $50 \%$ and $70 \%{ }^{10}$ Patients with diabetes mellitus are generally known to be more susceptible to infections. Although diabetes mellitus increases the risk of Fournier's gangrene, the effect of glycemic regulation on treatment remains controversial. Laor et al. ${ }^{11}$ showed that although diabetes contributes to the formation of Fournier's gangrene, it does not affect treatment outcomes. However, Laor et al. ${ }^{11}$ reported that seven of the 30 patients with Fournier's gangrene had chronic renal failure and six of these resulted in death. They also stated that chronic renal failure is a determining factor affecting treatment outcomes. Only one of our patients had chronic renal failure. Alcohol and smoking have also been shown to be associated with Fournier's gangrene. ${ }^{12}$ Of our patients, seven $(50 \%)$ were smoking and two (14\%) were drinking alcohol. The common denominator of all concomitant risk factors is deterioration of the immune resistance in the organism due to decreased cellular immunity. ${ }^{1}$ Palmer et al. ${ }^{13}$ reported that the location of necrosis in Fournier's gangrene affected the outcome of treatment. In our patients, necrosis was observed in perianal region in nine patients, in right inguinal region in one patient, in right gluteal region in one patient, extending from perianal region to scrotum in one patient, extending from perianal region to right gluteal region in one patient and extending from perianal region to right gluteal region and right medial thigh in one patient. The bacteria isolated in Fournier's gangrene are those that form the normal skin and mucosal flora of the urogenital and perianal regions. These colonizations are often polymicrobial and generally include both aerobic and anaerobic microorganisms. ${ }^{14}$ E. coli, Klebsiella, Staphylococcus, Streptococcus, Proteus, Pseudomonas, Bacteroides and Clostridium spp. are the most common microorganisms. ${ }^{15}$ In our patients, microbiological examination of tissue swab samples obtained during surgical debridement revealed E. coli in two patients, P. mirabilis in one patient and M. morgagnii in one patient.

The main principles of treatment are aggressive hemodynamic stabilization, parenteral broad-spectrum antibiotics and emergency surgical debridement. However, early surgical debridement is the mainstay of this combined treatment. Necessary debridements are performed by applying a series of re-explorations every 24-48 hours. They are very useful in controlling the extent of necrosis. It has been reported 
that this requires an average of 3.5 debridement procedures per patient. ${ }^{16}$ In our case series, a mean of 2.2 debridement was performed per patient. Urinary and fecal diversion may be necessary to protect the wound from contamination. Although there is no general consensus on colostomy, it is recommended to apply if there is extensive sphincter damage or large perineal wounds. ${ }^{17}$ Fecal diversion was achieved by colostomy in three patients in our study. One of them was transverse loop colostomy and two were sigmoid loop colostomies. Transverse loop colostomy was performed during the first operation. The other two sigmoid loop colostomies were performed in the first session after debridement. Urinary diversion was achieved by suprapubic catheterization in two of our patients.

As a result of aggressive surgical debridement, the common result is large tissue defects. Therefore, wound care is an important part of treatment in Fournier's gangrene. ${ }^{18}$ The final step in the treatment of Fournier's gangrene is the closure of a large wound defect. Most cases, especially small defect wounds, simply heal secondary. For defects that are slightly larger, primary closure may be sufficient. However, the most commonly used and preferred method for large defect wounds is skin grafts. ${ }^{16}$ Four of our patients underwent primary closure (Figure 3) and three patients underwent grafting. The remaining seven patients were left for secondary recovery. Vacuum-assisted closure (VAC), which has gained popularity in recent years, has accelerated wound healing and contributed significantly to this highly

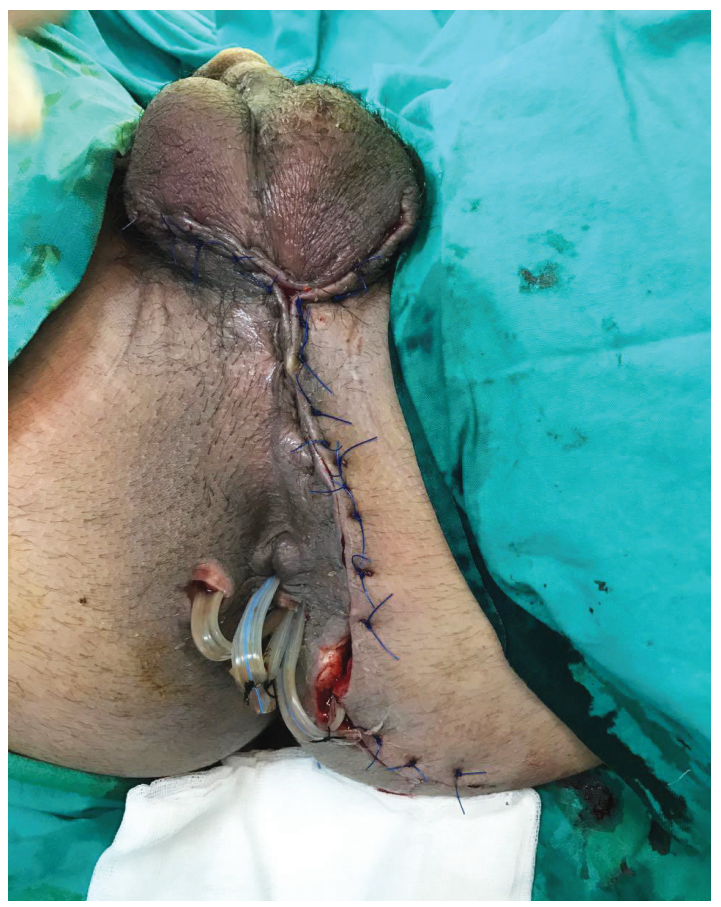

Figure 3. Primary closure after debridements and hyperbaric oxygen therapy for Fournier's gangrene troubled period of patients with minimal skin defects. ${ }^{19} \mathrm{We}$ used VAC treatment in five patients. It has been reported that $\mathrm{HBO}$ treatment reduces systemic toxicity, limits necrosis and reduces mortality with surgery and antibiotherapy. ${ }^{16} \mathrm{HBO}$ was used in eight of our patients. The use of HBO treatment may have played a role in our low mortality rate. The course of the disease is often difficult to predict. Laor et al. ${ }^{11}$ found FGSI by adapting the Acute Physiological and Chronic Health Assessment II score in relation to the prognosis of the disease. ${ }^{12}$ The authors showed that FGSI score predicts mortality of $75 \%$ and survival of $78 \%$. The FGSI score, which arouses great interest in the literature, is a valid and effective score widely used in many studies to determine the clinical outcome of the disease. In our study, the mean FSGI was found to be 5.2 (range=1-14). In the study of Yllmazlar ${ }^{18}$, by combining FSGI, age and dissemination, they predicted a mortality rate of $94 \%$ and a life expectancy of $81 \%$ in a series of 80 cases using a scoring system called the UFSGI score. In our study, UFSGI was found to be 7.8 (range=1-16). LRINC is another scoring system used to evaluate mortality and morbidity in Fournier's gangrene. It is calculated over laboratory values. The mean LRINC value in our patients was 5.3 (range $=2-9$ ). Cases with LRNIC values below 6 were considered as low risk. In conclusion, this life-threatening disease requires caution even in very small lesions of the perianal and urogenital regions. Fournier's gangrene should be suspected in patients presenting with complaints about this region. Early intervention is vital in these cases and extensive surgical debridement should be performed immediately. A multidisciplinary approach with general surgery, urology, gynecology and plastic surgery is required in this disease where extensive surgical debridement is the basis of treatment.

\section{Ethics}

Informed Consent: Retrospective study.

Peer-review: External and internal peer-reviewed.

\section{Authorship Contributions}

Surgical and Medical Practices: T.G., I.S., Concept: T.G., Design: T.G., A.Z.B., Data Collection or Processing: T.G., Analysis or Interpretation: T.G., Literature Search: T.G., Y.K., İ.S., Writing: T.G., M.D.

Conflict of Interest: No conflict of interest was declared by the authors.

Financial Disclosure: The authors declared that this study received no financial support.

\section{References}

1. Eke N. Fournier's gangrene: a review of 1726 cases. Br J Surg 2000;87:718728 
2. Yanar H, Taviloglu K, Ertekin C, Guloglu R, Zorba U, Cabioglu N, Baspinar I. Fournier's gangrene: risk factors and strategies for management. World J Surg 2006;30:1750-1754.

3. Morpurgo E, Galandiuk S. Fournier's gangrene. Surg Clin North Am 2002;82:1213-1224.

4. Y1lmazlar T: Fournier Gangreni. In : Anorektal Bölgenin Selim Hastalıkları, Eds . Mentefl, Bulut, Alabaz, Leventoğlu, Sayfa: 267-277, 2011

5. Levenson RB, Singh AK, Novelline RA. Fournier gangrene: role of imaging. Radiographics 2008;28:519-528.

6. Altarac S, Katusin D, Crnica S, Papes D, Rajkovic Z, Arslani N. Fournier's gangrene: etiology and outcome analysis of 41 patients. Urolint 2012;88:289-993.

7. Corcoran AT, Smaldone MC, Gibbons EP, Walsh TJ, Davies BJ. Validation of the Fournier's gangrene severity index in a large contemporary series. J Urol 2008;180:944-948.

8. Tang LM, Su YJ, Lai YC. The evaluation of microbiology and prognosis of Fournier's gangrene in past five years. Springerplus 2015;4:14.

9. García Marín A, Martín Gil J, Vaquero Rodríguez A, Sánchez Rodríguez T, de Tomás Palacios J, Lago Oliver J, Turégano Fuentes F. Fournier's gangrene: analysis of prognostic variables in 34 patients. Eur J Trauma Emerg Surg 2011;37:141-145.

10. Dahm P, Roland FH, Vaslef SN, Moon RE, Price DT, Georgiade GS, Vieweg J. Outcome analysis in patients with primary necrotizing fasciitis of the male genitalia. Urology 2000;56:31-35.
11. Laor E, Palmer LS, Tolia BM, Reid RE, Winter HI. Outcome prediction in patients with Fournier's gangrene. J Urol1995;154:89-92.

12. Nisbet AA, Thompson IM. Impact of diabetes mellitus on the presentation and outcomes of Fournier's gangrene. Urology 2002;60:775-779.

13. Palmer LS, Winter HI, Tolia BM, Reid RE, Laor E. The limited impact of involved surface area and surgical débridement on survival in Fournier's gangrene. Br J Urol1995; 76:208-212.

14. .Jones RB, Hirschmann JV, Brown GS, Tremann JA. Fournier's syndrome: Necrotizing subcutaneous infection of the male genitalia. J Urol 1979;122:279-282.

15. Hyung Min Hahn, Kwang Sik Jeong, Dong Ha Park, Myong Chul Park, Il Jae Lee Analysis of prognostic factors affecting poor outcomes in 41 cases of Fournier gangrene. Ann Surg Treat Res 2018;95:324-332.

16. Yllmazlar T: Fournier Gangreni. In : Anorektal Bölgenin Selim Hastalıkları, Eds. Menteş, Bulut,Alabaz, Leventoğlu,Sayfa: 267-277, 2011

17. Morpurgo E, Galandiuk S. Fournier's gangrene. Surg Clin North Am 2002;82:1213-1224.

18. Yllmazlar T. Fournier Gangreni: Sinsi, Öldürücü, Ancak TedaviEdilebilir Hastalık. Kolon Rektum Hast Derg 2012;22:45-49.

19. Ozturk E, Ozguc H, Yilmazlar T. The use of vacuum assisted closure therapy in the management of Fournier's gangrene. Am J Surg 2009;197:660-665. 